\title{
Research, Innovation and Technology transfer: Concepts, World wide Experience and Prospects for its Development in Romanian Universities
}

\author{
Sebastian-Călin VAC, Liana Maria VAC, Vasile Lucian NAS \\ Faculty of Horticulture, University of Agricultural Sciences and Veterinary Medicine of Cluj Napoca, 3-5, \\ Mănăștur Street, Cluj Napoca, Romania; \\ * corresponding author: calin.vac@usamvcluj.ro
}

Bulletin USAMV series Agriculture 72(1)/2015

Print ISSN 1843-5246; Electronic ISSN 1843-5386

DOI 10.15835/buasvmcn-agr: 11196

\begin{abstract}
In the period 2007-2013, the budget sector research, development, innovation and technology transfer (RDITT) in Romania was about 4 billion euro, i.e. an average of about $0.47 \%$ of Romania's GDP in the seven years. By comparison, in the German State of Baden-Wuerttemberg (BW) is invested annually in RDITT about 5.1\% of state GDP, the industrial sector contributes nearly $80 \%$ of investments. A decisive role in the development of the RDITT in BW it has RDITT catalyst institutions such as Max-Planck Society, Fraunhoffer Society, Helmholtz Association of German Research Centers, Innovation Alliance, Steinbeis Foundation. This research aims to reveal the huge potential and benefits it can bring research, innovation and technology transfer in sustainable development of agriculture in Romania using catalyst institutions model. The material used in this study was experts of academia, experts of economics, promoting documents and laboratories visited at the University of Tubingen and at the Natural and Medical Sciences Institute of Reutlingen, Germany. The methods used were documentation, real visiting of the two institutions and analysis the facts and the documents. The conclusion is that using the European models of technology transfer (especially the German model), all the benefits will be found in the future in Romanian economy, bringing added value to the quality of life and wellbeing.
\end{abstract}

Keywords: technology transfer, research, innovation, sustainable development, Romania

\section{TECHNOLOGY TRANSFER CONCEPT}

The term "technology transfer" encompass many different interpretations and views depending on the organizations' objectives, research background, researchers, developers, users, research areas and disciplines and underlying perspective (Wahab, 2012).

Generally speaking, technology transfer can be defined as the process of movement of technology from one entity to another. It can be estimated that the transfer was successful if the receiving entity can effectively utilise the technology transferred and eventually assimilate it (Ramanathan, 1994).

The term "technology transfer", including a "knowledge transfer" is used to describe the process by which ideas, concepts and technology informations are moved from a laboratory to the marketplace (Phillips, 2002; Williams and Gibson, 1990). This term may define also the transfer of knowledge and concept from technologically developed to less developed countries (Derakhshani, 1983; Putranto et al., 2003). A broader definition was defined by other authors, considering that the technology transfer is the movement of knowledge, skill, organisation, values and capital from the point of generation to the site of adaptation and application (Mittleman and Pasha, 1997).

In a very restrictive sense, where technology is considered as information, technology transfer 
is sometimes defined as the application of information into use (Gibson and Rogers, 1994).

The economists tend to define technology on the basis of the properties of generic knowledge, focusing particularly on variables that relate to production and design. Management researchers are more likely than others to focus on intra-sector transfer and the relation technology transfer to strategy. The recent researchers have focused on alliances pertain to the development and transfer of technology (Zhoa and Reisman, 1992).

One of the definitions that we consider as the most suitable for the concept of technology transfer is formulated by Association of University Technology Managers (2004): ,technology transfer is the process of designating the formal transfer to industry of discoveries resulting from university or private research, for marketing purposes under form of new products and / or services".

\section{GOOD PRACTICES AROUND THE WORLD}

There are several models to realise technology transfer around the world. First, we would like to present some aspects of economically advanced countries, in United States of America (USA) or Western Europe.

According to Technology Transfer Handbook for the U.S. Geological Survey (Beth et al., 2003), "the concept of technology transfer from Federal laboratories is to get the ideas, inventions, and technologies developed with taxpayer dollars into the hands of the private sector as quickly as possible, and in forms useful to that community. The idea is to get U.S. companies and other private sector entities involved in the development of Federal technology and technology products at an early stage so that the end result is useful to U.S. industry and can make the United States more competitive in world markets. [...] Technology transfer is mandated by law. Federal research agencies must support activities to enhance the awareness, adoption, and use of their technology products. By law, technology transfer should be an element in all Federal researchers' performance plans. The law states, „Technology Transfer consistent with the mission responsibilities, is a responsibility of each laboratory science and engineering professional." (Chapter 63 USC 15, Sec. 3710, (a)(2)). Technology transfer programs are the way to move federally funded research products and technologies into commercial practice. For researchers and Federal managers, this means that the products of your research programs can obtain increased visibility and value, and demonstrate the relevance of an agency in meeting the needs of your constituents. This also brings recognition to you as inventors and managers of the research development".

However, in the USA, where the most of advanced research organizations are located (http://research.webometrics.info/en/world), the first steps towards technology transfer goes back nearly a century ago. As Berkovitz (2006) stated, „Universities are viewed by many as engines of economic growth and continue to be cited as an important factor in regional technology development and revitalization. However, the process of university-led economic development takes considerable time and patience that is often outside of the immediate demands of the political process". Link (2002) concludes with the example that "the development of North Carolina's Research Triangle Park was the result of deliberate public policies that began in the 1920 s and took 50 years to realize tangible economic benefit in terms of job growth and enterprise development". In terms of job growth and business development, Sturgeon (2000) finds also that the genesis of Silicon Valley "may be traced to the early twentieth century."

Coming to Europe, one of the most important research and technology transfer centre, included in the Wageningen University Research Centre (WUR, Netherlands), assumed by their RDI strategy that „it is necessary to generate a snowball effect to boost innovation: many clients and (small) companies use our findings to generate different applications, including completely unexpected ones, for the benefit of society. We believe that the best way to guarantee the broad dissemination of new findings is by taking the lead in this transfer process, in order to maximise their use as well as further development of academic knowledge." (http://www.wageningenur.nl/en/ExpertiseServices / Facilities / Knowledge-transfervalorisation.htm).

At the initiative of the economic environment and the Chamber of Commerce of Liege, Belgium, in 1989 Liege University started his own Technology Transfer Office as a Company-University Interface, in order to fulfill his third mission: service to the community (http://www.interface.ulg. 
ac.be/, https://www.ulg.ac.be/cms/a_16290/ en/technology-transfer-office). Being a pioneer in implementing a coherent strategy for knowledge transfer in the science sector, for the last 10 years, Liege University promoted technological development, has been involved in regional structural changes (setting-up of technology parks and clusters, cooperation between partners from scientific and economic) and devoted half of the research budget to projects involving cooperation with companies in order to further extend their innovation and development potential (http:// www.uni-gr.eu/en/doctorates-research / knowledge-technology-transfer/university-ofliege.html).

As part of the Universities of Lorraine, the three french universities in Nancy and Paul-Verlaine University have decided to merge together, in the area of knowledge and technology transfer, in one department of knowledge transfer, based on two innovative pioneers (Metz and Nancy) having two locations: one being for engineering and the other for legal sciences. This department manages between 300 and 350 contracts a year in Lorraine (excluding the French national research agency ANR (The French National Research Agency) and European contracts) with an average turnover of $€ 7$ million a year. Since 2006 the department has processed more than 60 projects in the field of innovation development and has over 57 categories of patents and ten trademark and software registrations (http://www.uni-gr.eu/ en/doctorates-research/knowledge-technologytransfer/university-of-lorraine.html).

In November 2008 the University of Luxembourg adopted its guide to promoting research, entitled "Guiding principles for the valorisation of research results and intellectual property rights". This guide aims to define a coherent and structured policy on optimising the results of research and also to provide useful information for managing intellectual property rights (such as patent rights, copyright etc.) in the academic context, as well as the main steps for optimising the results, competences and technologies developed within the University. Through its policy on the optimisation of results and intellectual property, the University undertakes in particular to develop a strong culture in favour of optimising research results by using a wide variety of means of doing so, such as contractual cooperation with the private sector, the systematic protection of intellectual property, the negotiation of rights transfer agreements (such as operating licences and the assignment of rights) and the creation of spin-offs (http://www. uni-gr.eu/en/doctorates-research/knowledgetechnology-transfer/university-of-luxembourg. html).

In the German State of Baden-Wuerttemberg (BW) is invested annually in RDITT about 5.1\% of state GDP (Gross Domestic Product), while the industrial sector contributes nearly $80 \%$ of investments (Cordis, R\&D in BW, http://cordis. europa.eu/baden-wuerttemberg/rd_en.html). The two universities in Stuttgart (University of Stuttgart, University of Hohenheim) promote technology transfer initiatives based on a broad network of investors, academic and research-based assistance for start-ups and spin-offs by scientists, good practices and suport from catalyst research institutes like Steinbeis Foundation or Fraunhoffer Society (http://www.euris-programme.eu/ en/documents - Technology Transfer Initiative Stuttgart Germany,https://www.uni-hohenheim. de/1603?\&L=1).

The liaison office for knowledge and technology transfer at Saarland University and the "Universität des Saarlandes Wissens- und Technologietransfer (WuT) GmbH" initiate and supervise cooperation between the university and regional companies (http://www.uni-gr.eu/ en/doctorates-research/knowledge-technologytransfer/saarland-university.html).

The University of Kaiserslautern has many years of expert experience with transfer processes and the structures required for these. With the Kontaktstelle für Information und Technologie (KIT - contact point for information and technology) set up by the Board of the university, the University of Kaiserslautern offers a central contact point for companies in the federal state of Rhineland-Palatinate. Just like the Research and EU Department, the KIT transfer centre also comes under the Vice-President for Research and Technology as a staff unit, to ensure that there is intensive contact with the Board of the university and on the theme of supporting research. In Rhineland-Palatinate the KIT is a member of the university association for the transfer of knowledge and technology „Navigator Wissenschaft - naWI“, in which as well as the University of Kaiserslautern 
- represented by the KIT - the University of Koblenz-Landau, the Johannes Gutenberg University Mainz and the University of Trier pursue a holistic approach to the promotion of innovation. The aims of the association are essentially to increase the effectiveness and efficiency of the transfer of knowledge and technology, the joint marketing of knowledge and technology, and intensive technology and know-how screening (http://www.uni-gr.eu/en/doctorates-research/ knowledge-technology-transfer/university-ofkaiserslautern.html).

\section{ROMANIAN EXPERIENCE}

In Romania, the entire $\mathrm{R} \& \mathrm{D}$ activity is coordinated by the Ministry of Education and Scientific Research, through the National Authority for Scientific Research and Innovation (http://www.research.ro/), based on the National Strategy for RDI, regulated by law (GD 929/2014). Funding RDI activities (and therefore technology transfer at the universities level) is provided through the Executive Unit for Financing Higher Education, Research, Development and Innovation (UEFISCDI) - a public institution with legal personality, subordinated to the Ministry of Education and Scientific Research (MECS), and from functional perspective to the MECS advisory Councils with responsibilities in higher education, scientific research, development and innovation (http://uefiscdi.gov.ro/).

Funding RDI activities is performed on financing projects submitted by universities and other research organizations in the National Plan for R \& D (PN). Until now, in Romania were conducted two National Plans CDI (PN I PN II 1999-2006 and 2007-2013) and is in public consultation PN III 2014-2020 (www.edu.ro).

In Romania during the period 2007-2013, the budget sector research, development, innovation and technology transfer (RDITT) was about 4 billion euro, i.e. an average of about $0.47 \%$ of Romania's GDP in the seven years, as reported by the Ministry of Education, National Authority for Scientific Research and Intermediary Body for Competitiveness (http://www.poscce.research. ro/ro/articol/2389/management-br-financiarsi-control-situatia-bugetului-alocat-axei-2-a-poscce, http://uefiscdi.gov.ro/userfiles/file/ROST/ PN2ro.pdf).
One of the three strategic objectives of national RDI system in Romania refers to the improvement of knowledge's potential and its transfer, in close relation to technological achievements and transfer from research area to economic environment, in order to become competitive and increase the international visibility of Romanian research and socio-economic performences, as supported by the Ministry of Education and Research via the National Plan for Research (http://uefiscdi.gov. ro/userfiles/file/ROST/PN2ro.pdf).

In the last 3-4 years, also in Romania it began to discuss about increasing the number of products and technology offers, through technology transfer mechanisms. Is just the beginning, but we present below the few strategic projects made public in Romania.

The first project we can mention and that have developed such activities, is a project called „Research for Industry“ (Catana and Cabuz, 2013; Romanian Institute of Sciences and Technology, project „Reasearch for Industry”), implemented by the Romanian Institute of Science and Technology. The project was co-funded by the Swiss-Romanian Cooperation Programme and the support of the Technology Transfer Office of the Polytechnic University of Lausanne (Ecole Polytechnique Fédérale de Lausanne).

Another project to mention, was developed by the Romanian Association for Technology Transfer and Innovation which aims through Urban Mobility Logistics Cluster „to support Oltenia region to adapt and change their industrial structures to unlock the groups potential and entrepreneurship blast for regional economic development and for addressing societal challenges" (http://www. arott.ro/index.php?menu_id=0\&lang=en). The Romanian Association for Technology Transfer and Innovation far gathered 47 members, including 14 research and development institutes (all in technical fields), 6 business and technology incubators, 3 science and technology parks, 21 centers for technological information or technology transfer, other private companies that conduct technology transfer.

Finally, at the universities have been created in recent years laboratories or research centers, innovation and technology transfer, with or without legal personality, which can be accredited and can operate according to the law (GD 1062/2011). Due to the poor financing of research, most centers 
have preferred to work without legal personality, as well as departments within universities, within their own sources of funding, or the projects developed (a small research budget involves a small number of projects financed, therefore a small number of research centers that are really self sufficient).

Developing research centers attached to universities was prevented also by the drastic measures taken by the Romanian authorities, occasioned by the global crisis triggered in 2008 (GD 34/2009). The effects of these measures are felt today in a largely.

Considering the significant differences related to the mentality, approaches and involvement on Technology Transfer Development, significantly reduced in Romanian universities comparing with Western European Universities, we consider this proposed topic to be scientifically, economically and socially relevant and to offer realistic perspectives for the future. The presentation of good case studies and practices from other countries with active Technological Centres may overcome the existing gaps in Romania and in its involvement in international networks of antreprenorial universities.

The material used in the analysis consists of material, human and scientific resources, detailed below.

The material resources consists of technology transfer centers visited by the authors in Germany: during the study visit held in Stuttgart, Germany, between 22 to 23 May 2014, at the event "1 ${ }^{\text {st }}$ Eastern European Innovation Partnership High Level Meeting", under the aegis "Danubian Transfer Centers (DTC)" made by Steinbeis Europa Zentrum (SEZ), with the topic "exchange of best practices in Innovation \& Technology Transfer and debate on an upcoming roadmap to stimulate the respective capabilities in the Danube Region", the authors visited and studied the german technology transfer model implemented at the University of Tubingen and at the Natural and Medical Sciences Institute of Reutlingen. On the other hand, it have been used in our study the promoting materials offered by the institutions named above.

We need to mention that SEZ is the official partner of the University of Agricultural Sciences and Veterinary Medicine from Cluj-Napoca, Romania (where the authors belong), in terms of technology transfer skills developed within the university, together with other universities in Romania, Slovakia, Hungary, Slovenia and Germany during the project "Danubian Transfer Centers (DTC)" developed by SEZ.

In our opinion, to develop technology transfer skills and projects, it should set up joint teams of experts to develop specific technology transfer projects, as follows:

\section{Materials for technology transfer}

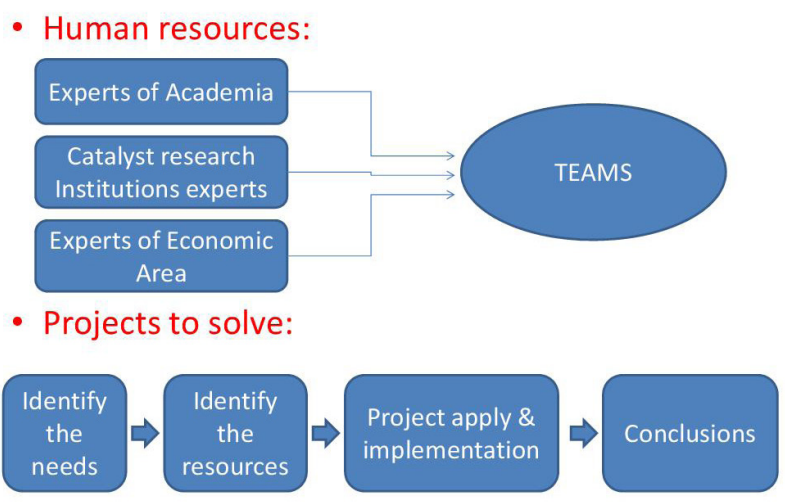

Fig. 1. Required Materials for Technology Transfer implementation

The human and scientific resources involved in our study was:

- human resources from academia (experts in Technology Transfer chain from academia): from the University of Agricultural Sciences and Veterinary Medicine of Cluj-Napoca, Romania (the authors), respectively experts in technology transfer from University of Tubingen, and from Natural and Medical Sciences Institute of Reutlingen; other academia persons invited at the event, from other universities members of DTC Network, about 20 persons;

- human resources from economics (experts in Technology Transfer chain from economy): experts from the two institutions named above, other experts from economics invited at the event, about 10 persons;

- cathalyst research institution experts (experts in Technology Transfer chain from cathalyst research institutions): experts from SEZ, about 10 persons.

The methods used in the article were documentation, real visiting of the two institutions and analysis the facts and the documents. The first project developed in this team was "Danubian Transfer Centers (DTC)". 
Last but not least, documentation and study visit to Stuttgart completes our previous visit in Germany, at Karlsruhe (20-21 February 2014), in the company SEZ, where we aimed to understand theoretically the German model of technology transfer. This was actually the first documentation and study visit in Germany on technology transfer, under the aegis "Danubian Transfer Centers (DTC)" made by SEZ, within the "Danube Innovation and Technology Transfer Centers” Project.

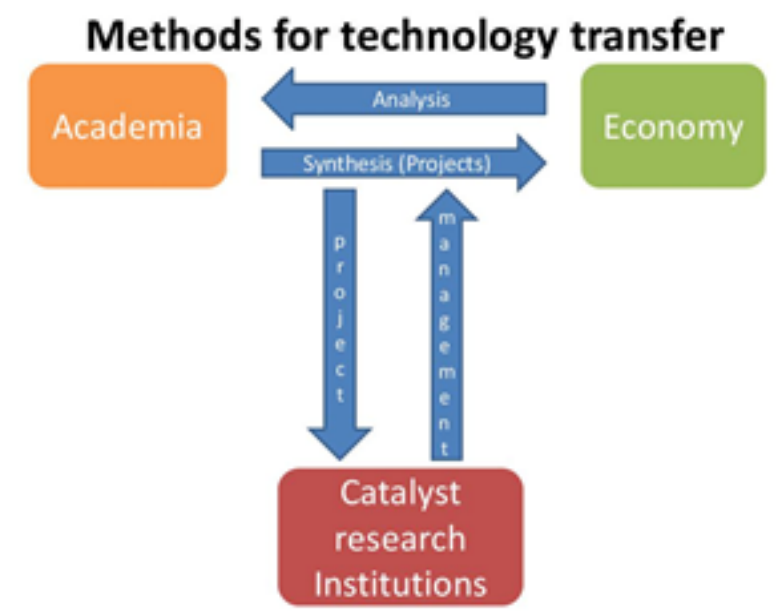

Fig. 2. Methods for Technology Transfer implementation

\section{CASE STUDY: UNDERSTANDING THE GERMAN MODEL OF TT}

In their presentations about Technology Transfer, during our visit, Phd professor Alfred Oberholz, chairman of DECHEMA - Gesellschaft Deutscher Chemiker, said "Research turns money into knowledge; innovation turns knowledge into money", and Phd professor Hugo Hammerle, manager of Natural and Medical Sciences Institute of Reutlingen, thinks "Technology transfer facilitate and speed up innovation".

Analysing the promoting documents and the facts during the visit, the authors can appreciate that a decisive role in the development of the RDITT in BW it had RDITT catalyst institutions such as Max-Planck Society, Fraunhoffer Society, Helmholtz Association of German Research Centers, Innovation Alliance, Steinbeis Foundation, as presented by the manager of The Natural and Medical Sciences Institute of Reutlingen in Germany (Fig.3).
Taking as example the German model (fig. 3), according to the authors, the actual situation of technology transfer chain in Romania looks like below (fig. 4).

On the other hand, according to the authors, technology transfer chain model that it should implement universities in Romania, should follow the advanced German model, as follows (fig. 5).

As can be seen in Fig. 4 and Fig. 5, in an advanced European modeled approach, the universities in Romania have to be classified into two categories, namely theoretical universities (in terms of research, they are limited to fundamental research, at most application oriented groundwork) and applied universities (in terms of research, the emphasis is on applied research).During the first three stages (IdeasFundamental research-Applied research), along with academics, it should also successfully work other research and innovation institutions, such as science or research and innovation parks, research institutes or innovation pilot stations (the emphasis is on research and innovation issues). According to the National Institute of Statistics in Romania (http://www.insse.ro/cms/ ro/content/activitatea-de-cercetare-dezvoltare), in Romania operates 34 institutions of the type of NRDI (National Research and Development Institute) in a quite poor financing conditions, barely being able to secure subsistence. It is worth noting that, of the $34 \mathrm{NRDI}$, none of them are in the agricultural area. Also, analysing the situation of scientific parks, as report by Development Plan of the Northwest Region (http://www.nordvest.ro/Document_Files/Planul-de-dezvoltareregionala-2014-2020/00001724/lob23_ PDR_2014_2020_Ianuarie_site.pdf), Romania is very poorly represented at this moment: 7 science and technology parks, all private, compared to the 90 universities in Romania, of which 58 are public universities. According to Global Innovation Report, currently, and in the last 10 years, research funding in Romania were on average $0.5 \%$ of GDP and the actual amounts really used were much lower (https://www.globalinnovationindex.org/ content.aspx?page=GII-Home). Regarding the universities (public ones), at least for the last 5 years, funding was provided only on basic funding level for teaching activities, and research has been carried out within their own budget, or sums drawn by own research projects. In the Table 1 
below, is presented research and development (R\&D) expenditure (\% of GDP) and its evolution in the last 10 years, in the most countries from Europe and United States of America, including the european union average, euro area average, or world average. R\&D covers basic research, applied research and experimental development. Analysing the data from Table 1 (collected data from the World Bank at the present time), it can be noted that the level of funds for research and development (and therefore technology transfer) in Romania is the lowest one compared to all the other European countries presented, compared to the European Union average, compared to the average of countries in the euro area, compared to the world average.Meanwhile, according to Innovation Index, 2012, the European average in terms of funds allocation for research is $3 \%$ of GDP and the leading regions of Europe (http://www. wipo.int/edocs/pubdocs/en/economics/gii/ gii_2012.pdf) allocated to this direction about 5\% of their GDP. Adding this information to the above, it can be explained the main reason why economic environment receives fewer results from research and innovation sphere, to develop and launch them into the market. Being just a few, these products can become competitive in very few cases, which further explains why the Romanian economy is well below the European average. On the other hand, the economic sector is very poorly represented in the services domain of services related to research- development-innovation. First, the Romania`s market economy does not yet have sufficient entrepreneurial education and the culture of the RDI sector, as have other countries in Europe or in USA (http://www.postprivatizare.ro/romana/ wp-content/uploads/2010/09/Studiu-EducatieAntreprenoriala.pdf). Then, the Romanian market economy is still recently (after 1989), with a poor experience, with an underdeveloped and almost unpredictable legal framework (http://ec.europa. eu/europe2020/pdf/csr2015/cr2015_romania_ en.pdf). In addition, this shaky economy has just gone through difficult years of global economic crisis, which explains, partialy, this very low capacity of the Romanian economic agents to invest in research.

In the last two stages (DevelopmentProducts), along with economic agents, directly interested in research findings and innovative products, should also operate in the same market other kind of structures: technological parks, spinoffs, business incubators, clusters (the emphasis is on technological processes - the other side of technology transfer). A brief nationwide overview of these concepts, is very enlightening: 7 science and technology parks, 36 clusters (http:// clustero.eu/asociatia-clusterelor-din-romania/), 10 business incubators (http://www.incubat.ro/ index.php?language $=$ en\&page $=3$ ) and in terms of spin-offs - they still do not have a legal definition (a legal national framework), only certain attributes
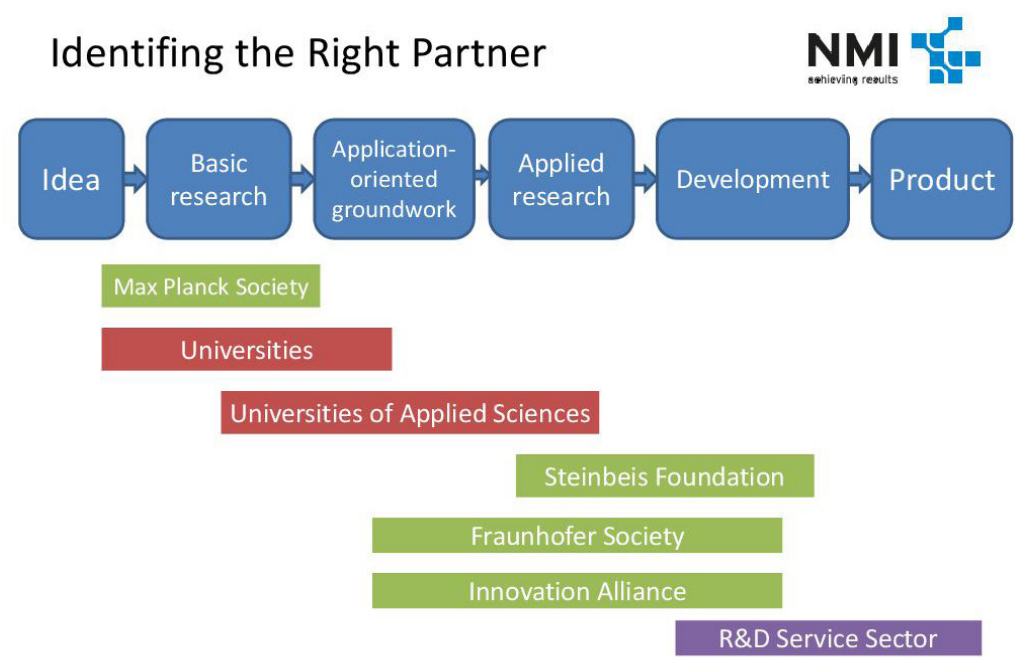

Helmhorst Association of German Research Centers

Fig. 3. The representation of Technology transfer chain, as presented by PhD prof. Hugo Hammerle (manager) at The Natural and Medical Sciences Institute of Reutlingen in Germany 
assigned by funding guidelines, so they are not yet sustainable structures.

Nevertheless, in Romania there is a complete lack of catalyst research and development management structures, as ones in the developed european economies (Fraunhofer, MaxPlanck, Steinbeis, Helmholtz). These structures should establish and limit the connection between academic and economic, to overcome cultural differences between academic and economic, to provide project management for each collaboration (projects) undertaken between the two parties and, thus, contribute to the competitiveness both in academia (research - innovation) and in the economic environment (development, market). Although the current romanian legal framework does not allow operation under the same conditions of such structures, this role could be taken in Romania by the innovative clusters, or "catalyst research and development institutes" that could generate the technology transfer. This technology transfer entities are defined in Cross Border Regional Innovation Strategy (Romania, Bulgaria) - „Methods for innovation and technology transfer in the industry," as the "backbone" of the regional economy.

Analyzing Fig. 3, Fig. 4 and Fig. 5 with the explanations given above, can be appreciated that in the chain of technology transfer in Romania the most underrepresented are economic sectors and especially the catalyst institutes. To fill this gap, obviously, it would be helpful to be used and

\section{Actual Technology Transfer Chain in Romania}

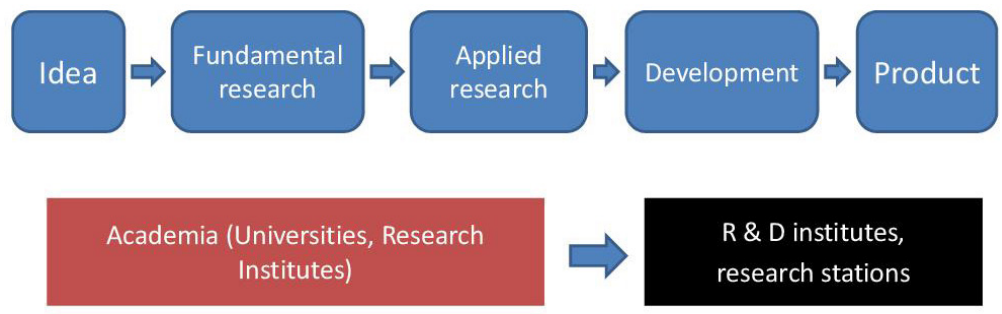

Innovative clusters

Fig. 4. Technology transfer chain in Romania (actual situation)

\section{Advanced Technology Transfer Chain in Romania}

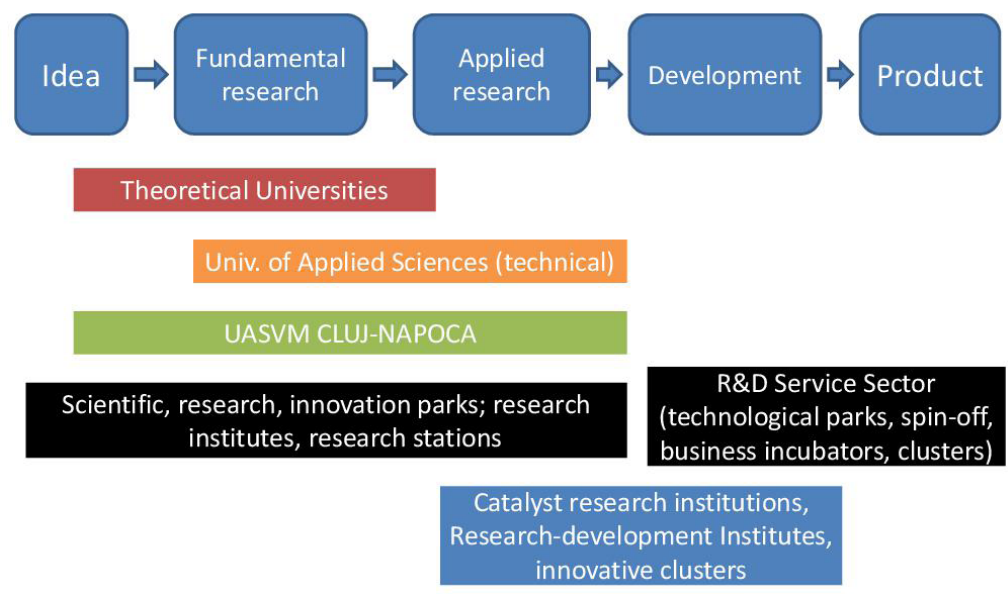

Fig. 5. Advanced technology transfer chain model in Romania (future situation) 
adapted models already implemented in Europe, whose performance has been proven in the last 30-40 years. Considering the level of involvement in research and development chain (in particular applied research - development, as in Fig. 3), we consider the models that would best suit to
Romania RDITT would be Fraunhoffer Society, Innovation Alliance or Steinbeis Foundation, and from these, the Steinbeis model is the nearest and most synthetic, so getting involved in smaller projects, and in large-scale projects.

Tab. 1. Research and development expenditure (\% of GDP) in countries from Europe and USA

\begin{tabular}{|c|c|c|c|c|c|c|c|c|c|c|}
\hline Country Name & 2003 & 2004 & 2005 & 2006 & 2007 & 2008 & 2009 & 2010 & 2011 & 2012 \\
\hline Austria & 2.24 & 2.24 & 2.46 & 2.44 & 2.51 & 2.67 & 2.71 & 2.80 & 2.77 & 2.84 \\
\hline Belgium & 1.87 & 1.86 & 1.83 & 1.86 & 1.89 & 1.97 & 2.03 & 2.10 & 2.21 & 2.24 \\
\hline Bulgaria & 0.48 & 0.49 & 0.46 & 0.46 & 0.45 & 0.47 & 0.53 & 0.60 & 0.57 & 0.64 \\
\hline Czech Republic & 1.20 & 1.20 & 1.22 & 1.29 & 1.37 & 1.30 & 1.35 & 1.40 & 1.64 & 1.88 \\
\hline Germany & 2.54 & 2.50 & 2.51 & 2.54 & 2.53 & 2.69 & 2.82 & 2.80 & 2.89 & 2.92 \\
\hline Denmark & 2.58 & 2.48 & 2.46 & 2.48 & 2.58 & 2.85 & 3.16 & 3.00 & 2.98 & 2.98 \\
\hline $\begin{array}{l}\text { Europe \& Central Asia } \\
\text { (developing only) }\end{array}$ & 0.57 & 0.56 & 0.62 & 0.60 & 0.65 & 0.65 & 0.72 & 0.71 & 0.71 & \\
\hline $\begin{array}{c}\text { Europe \& Central Asia (all } \\
\text { income levels) }\end{array}$ & 1.79 & 1.77 & 1.72 & 1.73 & 1.73 & 1.82 & 1.91 & 1.87 & 1.87 & 1.95 \\
\hline Euro area & 1.86 & 1.84 & 1.84 & 1.86 & 1.87 & 1.99 & 2.09 & 2.10 & 2.11 & 2.14 \\
\hline Spain & 1.05 & 1.06 & 1.12 & 1.20 & 1.27 & 1.35 & 1.39 & 1.40 & 1.36 & 1.30 \\
\hline Estonia & 0.77 & 0.85 & 0.93 & 1.13 & 1.08 & 1.28 & 1.41 & 1.62 & 2.37 & 2.18 \\
\hline European Union & 1.86 & 1.82 & 1.82 & 1.84 & 1.84 & 1.94 & 2.04 & 2.03 & 2.04 & 2.06 \\
\hline Finland & 3.44 & 3.45 & 3.48 & 3.48 & 3.47 & 3.70 & 3.94 & 3.90 & 3.80 & 3.55 \\
\hline France & 2.18 & 2.16 & 2.11 & 2.11 & 2.08 & 2.12 & 2.27 & 2.24 & 2.25 & 2.26 \\
\hline United Kingdom & 1.73 & 1.67 & 1.70 & 1.72 & 1.75 & 1.75 & 1.82 & 1.77 & 1.78 & 1.72 \\
\hline Greece & 0.57 & 0.56 & 0.60 & 0.59 & 0.60 & & & & 0.67 & 0.69 \\
\hline Croatia & 0.96 & 1.05 & 0.87 & 0.75 & 0.80 & 0.90 & 0.85 & 0.75 & 0.76 & 0.75 \\
\hline Hungary & 0.94 & 0.88 & 0.94 & 1.01 & 0.98 & 1.00 & 1.17 & 1.17 & 1.22 & 1.30 \\
\hline Ireland & 1.16 & 1.23 & 1.25 & 1.25 & 1.28 & 1.45 & 1.69 & 1.69 & 1.66 & 1.72 \\
\hline Italy & 1.10 & 1.09 & 1.09 & 1.13 & 1.17 & 1.21 & 1.26 & 1.26 & 1.25 & 1.27 \\
\hline Luxembourg & 1.65 & 1.63 & 1.56 & 1.66 & 1.58 & 1.66 & 1.74 & 1.51 & 1.41 & 1.44 \\
\hline North America & 2.52 & 2.46 & 2.47 & 2.50 & 2.56 & 2.69 & 2.74 & 2.65 & 2.66 & 2.68 \\
\hline Netherlands & 1.92 & 1.93 & 1.90 & 1.88 & 1.81 & 1.77 & 1.82 & 1.86 & 2.03 & 2.16 \\
\hline Norway & 1.71 & 1.57 & 1.51 & 1.48 & 1.59 & 1.58 & 1.76 & 1.68 & 1.65 & 1.65 \\
\hline Poland & 0.54 & 0.56 & 0.57 & 0.56 & 0.57 & 0.60 & 0.67 & 0.74 & 0.76 & 0.90 \\
\hline Portugal & 0.71 & 0.74 & 0.78 & 0.99 & 1.17 & 1.50 & 1.64 & 1.59 & 1.52 & 1.50 \\
\hline Romania & 0.39 & 0.39 & 0.41 & 0.45 & 0.52 & 0.58 & 0.47 & 0.46 & 0.50 & 0.49 \\
\hline Serbia & 0.57 & 0.32 & 0.43 & 0.49 & 0.36 & 0.38 & 0.92 & 0.79 & 0.78 & 0.99 \\
\hline Slovak Republic & 0.57 & 0.51 & 0.51 & 0.49 & 0.46 & 0.47 & 0.48 & 0.63 & 0.68 & 0.82 \\
\hline Slovenia & 1.27 & 1.39 & 1.44 & 1.56 & 1.45 & 1.65 & 1.86 & 2.11 & 2.47 & 2.80 \\
\hline Sweden & 3.80 & 3.58 & 3.56 & 3.68 & 3.43 & 3.70 & 3.62 & 3.39 & 3.39 & 3.41 \\
\hline Turkey & 0.48 & 0.52 & 0.59 & 0.58 & 0.72 & 0.73 & 0.85 & 0.84 & 0.86 & \\
\hline Ukraine & 1.11 & 1.08 & 1.17 & 0.95 & 0.85 & 0.85 & 0.86 & 0.83 & 0.74 & \\
\hline United States & 2.55 & 2.49 & 2.51 & 2.55 & 2.63 & 2.77 & 2.82 & 2.74 & 2.76 & 2.79 \\
\hline W & 2.08 & 2.03 & $\frac{2.02}{\text { attorlCR }}$ & $\frac{2.03}{2.03(1)}$ & $\frac{2.00}{n 7 S_{6}}$ & 2.07 & 2.12 & 2.11 & 2.13 & \\
\hline
\end{tabular}


The following facts provide a snapshot of the expertise and resources that Steinbeis Foundation was able to make available to and with their clients in the year 2013 (www.stw.de):

978 Steinbeis Enterprises worldwide, 145 Mio. EUR total turnover,

730 professors,

1,708 employees,

3,544 contractors.

\section{CONCLUSIONS}

Steinbeis model can be successfully applied in addressing RDITT projects funded by Horizon2020, the RDITT European Union program with a budget of 80 billion euro. All the universities can and must develop using all the pillars of the program, especially on scientific excellence (for reputed or young researchers), biotechnologies, societal challenges (health, agriculture and bio-economy, energy and climate policies). Also, the system can and should be used in accessing projects financed from structural instruments, from national research plan, but also from external or internal private sources of financing.

German model of technology transfer, and especially the Steinbeis model, is first of all a fundamental change of approach to partnerships established between academia and economic, optimizing RDITT processes, thereby contributing to significant economic growth in Romania.

Approach of a European model of technology transfer and its adaptation to the legislation and realities of Romania, of the one part, it will become possible the acceleration of defining, assuming and integrating technology transfer strategy at the universities level; on the other hand, it will create the institutional economic boost in all universities, to stimulate the entire technology transfer chain: generation of business $==>$ increase of the universities revenues $==>$ increase the investments in research and innovation (infrastructure, capacity building, processes) $==>$ stimulating research, development and innovation, actually of the entire chain of technology transfer. Using the german model, all these benefits will be found in the future in Romanian economy, bringing added value to the quality of life and wellbeing.

To manage these processes to be implemented at universities in Romania, in our view it must be approached and fulfilled several objectives:
- increasing the competitiveness of academia (research and innovation) by applying successful studied technology transfer models and adapted to economic and social realities of Romania;

- developing the university`s own technology transfer strategy through further analysis of the mechanisms and similar environments from countries more developed then Romania;

- stimulating research and innovation in universities by providing modern and efficient management, promoted by Centers for Project Management and Technology Transfer, inside or outside the universities, but related to universities, for all technology transfer project proposals within this institutions;

- increasing the visibility of the university's concern for RDITT, by attending scientific conferences in the area of technology transfer;

- raising awareness of the benefits of technology transfer at local and regional level by raising awareness of decision makers in this regard;

- enhancing collaboration between universities and business environment in order to raise awareness of the economic actors on the importance and relevance of research, innovation and technology transfer in their economic and social future development, to gain experiences together and be able to solve in the same team as many of the challenges of social and economic environment.

Acknowledgements. The authors are grateful to the collegues and experts from Steinbeis Europa Zentrum both for inviting to Karlsruhe event in February 2014 and to Stuttgart event in May 2014, for the promoting documents they gave to us, for involving our university in DTC network and for supporting us in our efforts to implement an efficient model of technology transfer within our university.

\section{REFERENCES}

1. Bercovitz, J., Feldmann, M. (2006). Entpreprenerial Universities and Technology Transfer: A Conceptual Framework for Understanding Knowledge-Based Economic Development. Journal of Technology Transfer. 31: 175-188

2. Beth, D., Strader, S., Mark, N. (2003). Technology Transfer Handbook for the U.S. Geological Survey. U.S. Geological Survey 
3. Catana, A., Cabuz, Al.I. (2013). The virtual technology transfer office - researchforindustry.ro. Revista de Politica Ştiintei si Scientometrie

4. Derakhshani, S. (1983). Factors affecting success in international transfers of technology - A synthesis, and a test of a new contingency model. Developing Economies. 21 (1983), 27-45

5. Gibson, D.V., Rogers, E.M. (1994). R\&D Collaboration on Trial: The Microelectronics and Computer Technology Consortium. Harvard Business School Press, Boston

6. Link, A.N., Scott, J.T. (2002). The Growth of Research Triangle Park. UNC Press

7. Mittleman, J.H., Pasha, M.K. (1997). Out from Underdevelopment Revisited: Changing Global Structures and the Remarking of the Third World. St. Martin's Press, New York

8. Phillips, R. (2002). Technology Business Incubators: How Effective Is Technology Transfer Mechanisms? Technology in Society. 24 (3): 299-316

9. Putranto, K., Stewart, D., \& Moore, G. (2003). International Technology Transfer of Technology and Distribution of Technology Capabilities: The Case of Railway Development in Indonesia. Technology in Society. 25 (1), 42-53

10. Ramanathan, K. (1994). The polytrophic components of manufacturing technology. Technological Forecasting \& Social Change. 46, 221-258

11. Sturgeon, T.J. (2000). How Silicon Valley came to be, Understanding Silicon Valley: The anatomy of an entrepreneurial region. Stanford University Press

12. Wahab, S.A., Che Rose, R., Osman, S.I.W. (2012). Defining the Concepts of Technology and Technology Transfer: A Literature Analysis. International Business Research. 5(1):61-71

13. William, F., Gibson, D. V. (1990). Technology Transfer: A Communication Perspective. Sage: Beverly Hills, CA

14. Zhao, L. M., Reisman, A. (1992). Towards Meta Research on Technology Transfer. IEEE Transaction on Engineering Management. 39 (1), 13-21

15. *** CORDIS, R\&D in Baden-Wuerttemberg, http://cordis. europa.eu/baden-wuerttemberg/rd_en.html

16. *** Cross Border Regional Innovation Strategy 2007-2013 (Romania-Bulgaria): the story of two regions, one strategy: to zoom in research and innovation industry, Romanian Association for Technology Transfer and Innovation, http://www.arott.ro/files/2-3.1-8/Strategia\%20 regionala $\% 20$ transfrontaliera $\% 20$ pentru $\% 20$ inovare. pdf

17. *** Development Plan of the Northwest Region 20142020, http://www.nord-vest.ro/Document_Files/Planulde-dezvoltare-regionala-2014-2020/00001724/lob23_ PDR_2014_2020_Ianuarie_site.pdf

18. *** European Commission, Country Report Romania 2015, http://ec.europa.eu/europe2020/pdf/csr2015/ cr2015_romania_en.pdf

19. *** GD 929/2014 - approving the National Strategy for Research, Development and Innovation 2014-2020

20. *** GD 1062/2011 - approving the Methodological Norms for the evaluation and classification for certification of units and institutions of the national system of research and development

21. *** GD 34/2009 - on the 2009 budget rectification and regulation of certain financial-fiscal

22. *** Global Innovation Report, https://www. globalinnovationindex.org/content.aspx?page=GII-Home

23. *** Innovation Index 2012, http://www.wipo.int/edocs/ pubdocs/en/economics/gii/gii_2012.pdf

24. *** Ministry of Education, National Authority for Scientific Research, http://uefiscdi.gov.ro/userfiles/file/ROST/ PN2ro.pdf

25. *** Ministry of Education and Research, National Plan for Research, Development and Innovation 2007 - 2013, http://uefiscdi.gov.ro/userfiles/file/ROST/PN2ro.pdf

26. *** Ministry of Education, Intermediary Body for Competitiveness, http://www.poscce.research.ro/ro/ articol/2389/management-br-financiar-si-controlsituatia-bugetului-alocat-axei-2-a-pos-cce

27. *** National Institutute of Statistics in Romania - The annual report of research-development in 2013, http:// www.insse.ro/cms/ro/content/activitatea-de-cercetaredezvoltare

28. *** National Authority for Scientific Research and Innovation, http://www.research.ro/

29. *** Post-Privatization Foundation, Promoting Entrepreneurial Education and Financing Opportunities, 2010, http://www.postprivatizare.ro/romana/ wp-content/uploads/2010/09/Studiu-EducatieAntreprenoriala.pdf

30. *** Ranking WEB of Research Centers, http://research. webometrics.info/en/world

31. *** Romanian Institute for Sciences and Technology, project "Reasearch for Industry”, http://www. researchforindustry.ro/

32. *** Steinbeis Foundation, www.stw.de

33. *** The Association of University Technology Managers, 2004, cité dans Conseil de la science et de la technologie du Québec, Chaînes de valorisation de résultats de la recherche universitaire recelant un potentiel d'utilisation par une entreprise ou par un autre milieu, 2006, p. 7

34. *** The clusters association from Romania, http:// clustero.eu/asociatia-clusterelor-din-romania/

35. *** The Executive Unit for Financing Higher Education, Research, Development and Innovation (UEFISCDI), http://uefiscdi.gov.ro/

36. *** The Ministry of Education and Scientific Research, www.edu.ro

37. *** The World Bank Group, http://data.worldbank.org/ indicator/GB.XPD.RSDV.GD.ZS

38. *** Wageningen University and Research centre (Wageningen UR), http://www.wageningenur.nl/en/ Expertise-Services/Facilities/Knowledge-transfervalorisation.htm

39. *** Liege University - Technology Transfer Office as a Company-University Interface, http://www.interface. ulg.ac.be/, https://www.ulg.ac.be/cms/a_16290/en/ technology-transfer-office, http://www.uni-gr.eu/en/ 
doctorates-research/knowledge-technology-transfer/ university-of-liege.html

40. *** Universities of Lorraine, Knowledge ant Technology Transfer Center, http://www.uni-gr.eu/en/doctoratesresearch/knowledge-technology-transfer/university-oflorraine.html

41. *** University of Luxembourg, Knowledge ant Technology Transfer Center, http://www.uni-gr.eu/en/doctoratesresearch/knowledge-technology-transfer/university-ofluxembourg.html

42. *** University of Stuttgart, Knowledge ant Technology Transfer Center, http://www.euris-programme.eu/en/ documents
43. *** University of Hohenheim, Knowledge ant Technology Transfer Center, https://www.uni-hohenheim. de/1603?\&L=1

44. ** Saarland University, Knowledge ant Technology Transfer Center, http://www.uni-gr.eu/en/doctoratesresearch/knowledge-technology-transfer/saarlanduniversity.html

45. ** University of Kaiserslautern, Knowledge ant Technology Transfer Center, http://www.uni-gr.eu/en/ doctorates-research/knowledge-technology-transfer/ university-of-kaiserslautern.html 